\title{
DESIGN AND ANALYSIS OF A PREMIUM EFFICIENCY (IE3) INDUCTION MOTOR
}

\author{
Pankaj A Sakpal ${ }^{1}$, Vijay Mohale ${ }^{2}$ \\ ${ }^{1}$ M.Tech Power Systems, Department of Electrical Engineering, Walchand College of Engineering, Sangli \\ pankaj.sakpal@walchandsangli.ac.in \\ ${ }^{2}$ Assistant Professor, Department of Electrical Engineering, Walchand College of Engineering, Sangli \\ vijay.mohale@walchandsangli.ac.in
}

\begin{abstract}
For designing an induction motor complete dimension of all the parts of the machine must be known in order to satisfy the customers required specifications. This paper presents the calculation offollowing design details. (a) The dimensions of the stator that includes stator packet length and diameter. (b) Details of stator windings and stator slots. (c) Design details of rotor and rotor slots. (d) Finally, the performance of motor. In order to get the above design details the designer needs the required customer specifications such as rated power output, rated voltage, speed, frequency, type of stator winding and its connection, type of rotor winding, working conditions, shaft extension and dimension details etc. The design example of $45 \mathrm{k} W$ cage motor is presented and various tests are also performed.
\end{abstract}

Keywords: Induction Motor; Designing; Premium Efficiency Motor; Efficiency; Losses; IEC 60034-30-1; IEC 600341 standard.

\section{Symbols:}

$\cos \phi=$ power factor

$\mathrm{f}=$ supply frequency, $\mathrm{Hz}$

$\mathrm{I}=$ average line current, $\mathrm{A}$

$\mathrm{n}=$ operating speed, $\mathrm{s}-1$

$\mathrm{p}=$ nu mber of pole pairs

$\mathrm{P}=$ power, $\mathrm{W}$

$\mathrm{P}_{0}=$ input power at no-load, $\mathrm{W}$

$\mathrm{P}_{1}=$ input power, excluding excitation $2, \mathrm{~W}$

$\mathrm{P}_{2}=$ output power, $\mathrm{W}$

$\mathrm{P}_{\mathrm{fe}}=$ Iron losses, $\mathrm{W}$

$\mathrm{P}_{\mathrm{fw}}=$ Friction and windage losses, $\mathrm{W}$

$\mathrm{P}_{\mathrm{L}}=$ load losses, $\mathrm{W}$

$\mathrm{P}_{\mathrm{LL}}=$ additional-load losses, $\mathrm{W}$

Pmech = mechanical power, $\mathrm{W}$

$\mathrm{P}_{\mathrm{T}}=$ total losses, $\mathrm{W}$

$\mathrm{R}=$ winding resistance, $\Omega$

$\mathrm{s}=\mathrm{slip}$, in per unit value of synchronous speed

$\mathrm{T}=$ machine torque, $\mathrm{N} \cdot \mathrm{m}$

$\mathrm{U}=$ average terminal voltage, $\mathrm{V}$

$\mathrm{U}_{0}=$ voltage at no-load, $\mathrm{V}$

$\mathrm{U}_{\mathrm{N}}=$ rated voltage, $\mathrm{V}$

$\mathrm{X}=$ Reactance, $\Omega$

$\mathrm{Z}=$ Impedance, $\Omega$

$\eta=$ Efficiency, $\%$

$\theta_{0}=$ initial winding temperature, ${ }^{\circ} \mathrm{C}$

$\theta \mathrm{a}=$ a mbient te mperature, ${ }^{\circ} \mathrm{C}$

$\theta \mathrm{w}=$ winding temperature, ${ }^{\circ} \mathrm{C}$

$\tau=$ time constant, $\mathrm{s}$

$\mathrm{ac}=$ ampere conductors

$\mathrm{K}_{\mathrm{W}}=$ winding factor

\section{INTRODUCTION}

Induction motors are widely used in domestic, commercial and various industrial applications. Mostly, the squirrel cage induction motor is used because of its simplicity, robustness and low cost, which has always made it very attractive, and it has therefore captured the leading place in industrial sectors.

High efficiency motors lead to significant reductions in energy consumptions and also reduces the environmental impact. Sustainable use and investments also demands increased motor reliability. Major energy savings are also gained through the use of variable speed drives (VSDs). An important measure for wide market acceptance of high efficiency motors is availability of harmonized standards, dealing with motor performance testing, efficiency classification, and display of ratings.

In this paper, motor is designed as per the design catalogues with this designed parameters the motor is tested. Its performance is calculated and compared with the actual performance obtained from the test results.

In the IEC 60034-30-1 the following efficiency classes are defined for induction motors (IE = International Efficiency):

1. Standard Efficiency (IE1)

2. High Efficiency (IE2)

3. Premium Efficiency (IE3)

4. Super Premiu m Efficiency (IE4)

In order to increase the efficiency the designer must calculate the losses check the motor performance. These losses may include stator copper losses, iron losses, friction 
and windage losses. In comparison with the standard (e.g. IE1) electrical motor, more iron and copper material are used.

Ac compared to IE1 motor the IE3 motors are heavier and bigger. Hence in order to increase the efficiency higher slot fill in the copper winding should be used, thinner laminations of improved steel properties should be used, air gap should be reduced, better design of cooling fan should be used to decrease the windage losses, use of special and improved bearings etc. can ensure higher efficiency in the motors.

\section{DESIGNING OF INDUCTION MOTORS}

A. Main dimensions

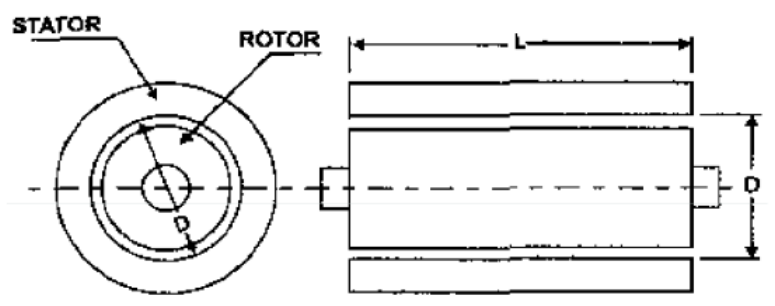

Figure 1.

$\mathrm{D}=$ Stator inner diameter,

$\mathrm{L}=$ length of stator packet.

Separation of D and L: The operating characteristics of an induction motor are mainly depend upon the ratio $L \tau$ i.e. by the ratio $L / D$ for a fixed number of poles. The factors influencing this choice are:

For minimum cost $L / \tau=1.5$ to 2 , for good power factor $L / \tau$ $=1$ to 1.25 , for good efficiency $L / \tau=1.5$, and for good overall design $L / \tau=1$. The value of $L / \tau$ should vary between 0.6 to 2 depending on the size of the machine and the characteristics required [1][2].

\section{B. Details of stator winding}

Total loadings:

1. Total Magnetic Loading: It's the total flux around the stator periphery at the air gap.

2. Total Electric Loading: It's the number of ampere conductors around the stator periphery.

Specific Loading:

1. Specific magnetic loading: it's the ratio of total flux around the air gap and area of flux path at the air gap. Basically, the specific magnetic loading is determined by: (a) maximum flux density in iron parts of machine, (b) magnetizing current and (c) core losses.

2. Specific electric loading: it's the ratio of total ampere conductor and stator periphery at air gap. Factors which influence the choice of specific electric loading are: (a) Temperature rise (b) size of machine (c) current density.
$\mathrm{C}_{0}=11 \mathrm{~B}_{\mathrm{av}} * \mathrm{ac}^{*} \mathrm{~K}_{\mathrm{w}} * 10^{-3}$ where,

$\mathrm{C}_{0}$ is output coefficient.

\section{Number of stator slots selection criteria}

For selection of stator slots following points should be considered:

1. Tooth pulsation loss: In open type slots, the slots should be so proportioned that minimum variations in air gap are produced. The effect of these variations is to produce tooth pulsation losses and noise. This effect can be minimized by using large nu mber narrow slots.

2. Leakage reactance: With large number of slots, larger the number of slots to insulate. Hence width of insulation becomes more and the leakage flux has longer path through air. Hence the leakage flu $x$ reduces.

3. Magnetizing current \& iron loss es: With large number of slots there will be excessive flux density in the teeth. Hence high magnetizing current and iron losses.

4. Cost: With large number of slots, large number of coils to wind and insulate and this involves increase in the cost.

So use many slots as economically as possible. Hence $\mathrm{q}$ should not be less than 2; otherwise leakage reactance would be high.

Number of conductor per slots should be even for double layer winding.

\section{Design details of rotor}

a. Length of air gap: In order to estimate the air gap length, the following expression is used

$1_{\mathrm{g}}=0.2+2 \sqrt{\mathrm{DL} \mathrm{mm}}$

Factors to be considered while estimating air gap are:

1. Power factor: The mmf required to send the flux through air gap is proportional to the product of flux density and length of air gap. Hence larger the air gap, large magnetizing current is drawn by the machine and the power factor is small.

2. Overload capacity: If the length of air gap is greater, the over load capacity is greater.

3. Pulsation losses: With larger air gaps, pulsation losses are less.

Hence, the length of air gap should be small as mechanically possible in order to keep down the magnetizing current and improve the power factor.

b. Nu mber of rotor slots selection criteria:

Following rules should be followed for selecting the number of rotor slots: The number of stator slots should not be equal to rotor slots. The difference between stator slots and rotor slots should not be equal to $\mathrm{p}, 2 \mathrm{p}$ or $5 \mathrm{p}$ to avoid synchronous cusps. The difference between stator slots and rotor slots should not be equal to $3 p$ to avoid magnetic locking. The difference between stator slots and rotor slots should not be equal to $1.2,(p \pm 1)$ or $(p \pm 2)$ to avoid noise and vibrations.

Output equation:

$\mathrm{Q}=\mathrm{C}_{0} * \mathrm{D}^{2} \mathrm{~L}^{*} \mathrm{n}_{\mathrm{s}}$ where, 


\section{E. Performance}

In an induction motor the total losses consist of copper losses, core losses and friction and windage losses are occurred. Hence the efficiency can be calculated as:

Efficiency at full load $\eta$ : Output/ (Output + losses)

\section{DESIGN EXAMPLE OF 45KW CAGE INDUCTIONMOTOR}

\section{A. Table I: Reference Data}

This data consists of required customer specifications, based on this data calculation of the parameters of motor is done.

\begin{tabular}{|l|l|l|l|l|}
\hline $\begin{array}{l}\text { Frequency } \\
\mathrm{Hz}\end{array}$ & $\begin{array}{l}\text { Voltage } \\
\mathrm{V}\end{array}$ & $\begin{array}{l}\text { Current } \\
\mathrm{A}\end{array}$ & $\begin{array}{l}\text { Power } \\
\mathrm{kW}\end{array}$ & Poles \\
\hline 50.0 & 415.0 & 76.00 & 45.00 & 2 \\
\hline
\end{tabular}

\section{B. Table II: Parameters}

\begin{tabular}{|l|l|}
\hline Parameters & Calculated values \\
\hline D (diameter) & $187 \mathrm{~mm}$ \\
\hline L (packet length) & $220 \mathrm{~mm}$ \\
\hline Turns per phase & 63 \\
\hline Stator conductor Per slot & $10.5=11$ \\
\hline Coil span & 18 \\
\hline Line current & $75.6 \mathrm{~A}$ \\
\hline Outside diameter & $374 \mathrm{~mm}$ \\
\hline Rotor diameter & $185.81 \mathrm{~mm}$ \\
\hline
\end{tabular}

\section{Calculations}

Following are the calculations of motor dimensions, stator design, rotor design, stator slots design, and the motor performance.

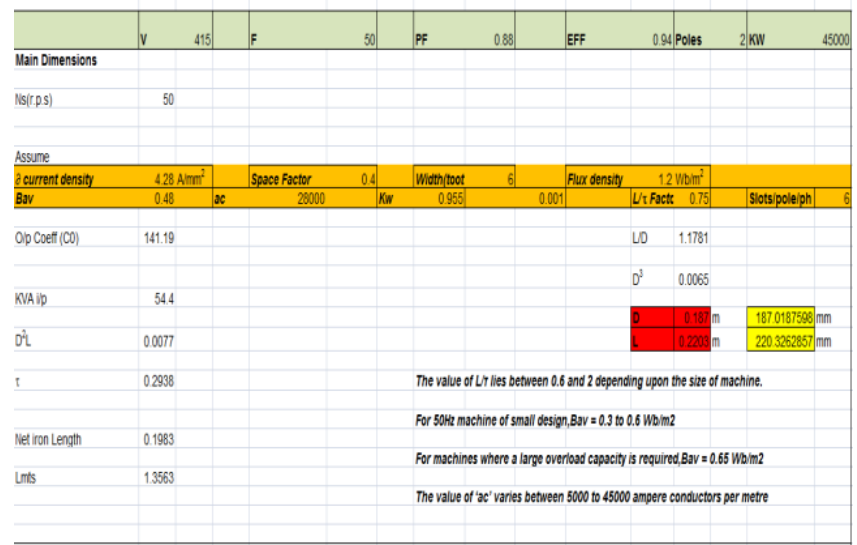

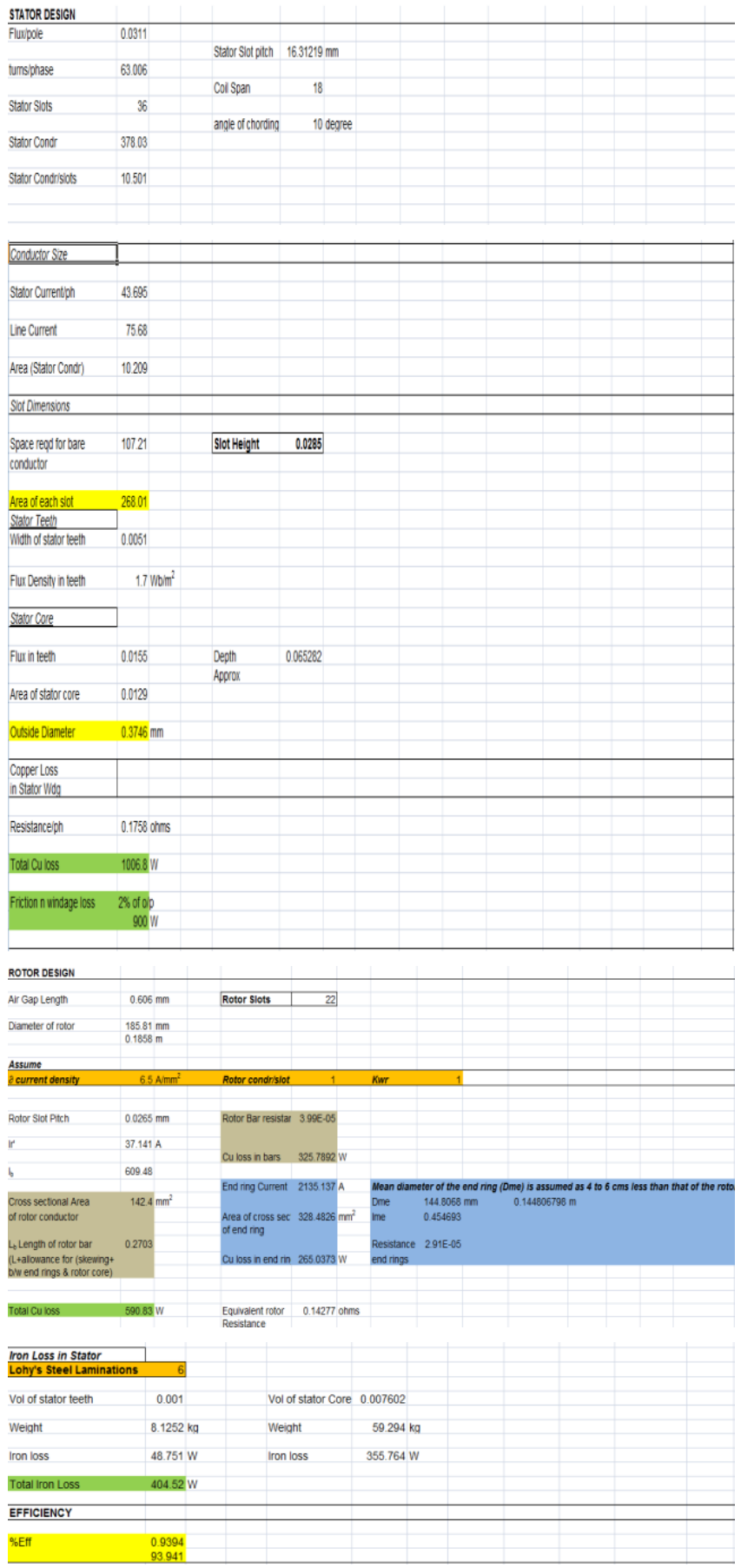

\section{SLOT DESIGN}

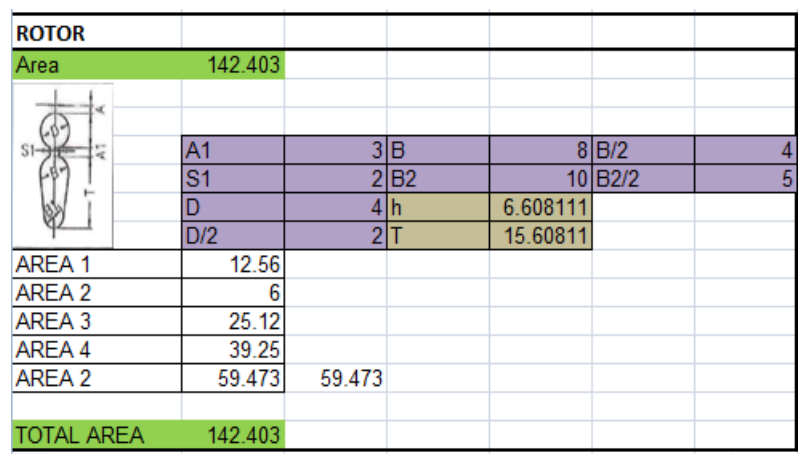




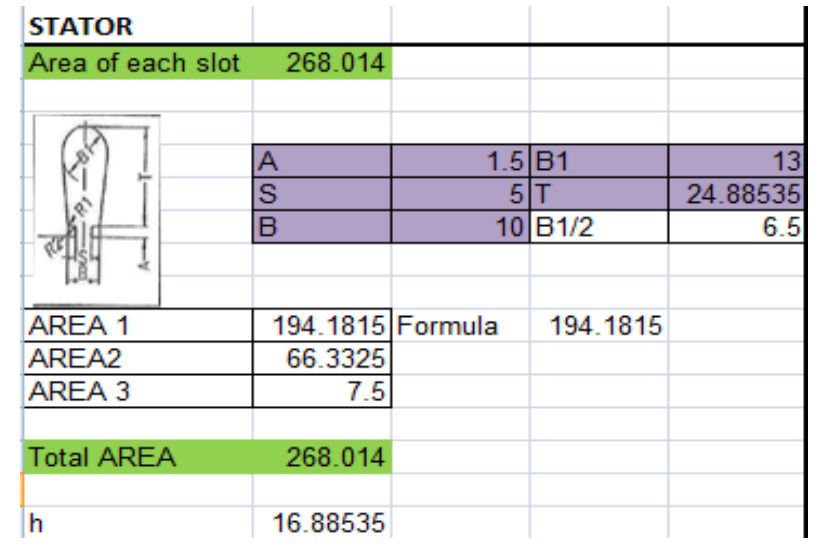

\section{V.MOTOR TYPE TEST RESULTS}

Following are the tests performed on motor:

- No load test

- Short Circu it test

- No-load characteristics

A. Table III: No load test

\begin{tabular}{|l|l|l|l|l|}
\hline $\begin{array}{l}\text { Frequency } \\
\mathrm{Hz}\end{array}$ & $\begin{array}{l}\text { Voltage } \\
\text { V }\end{array}$ & $\begin{array}{l}\text { Current } \\
\mathrm{A}\end{array}$ & $\begin{array}{l}\text { Power } \\
\text { input } \\
\mathrm{kW}\end{array}$ & $\begin{array}{l}\text { Power } \\
\text { factor }\end{array}$ \\
\hline 50.0 & 456.5 & 21.48 & 1.570 & 0.09 \\
\hline 50.0 & 415.0 & 18.27 & 1.408 & 0.11 \\
\hline 50.0 & 373.5 & 15.87 & 1.299 & 0.13 \\
\hline
\end{tabular}

\section{B. Table IV: Short Circuit test}

\begin{tabular}{|l|l|l|l|l|}
\hline $\begin{array}{l}\text { Frequency } \\
\mathrm{Hz}\end{array}$ & $\begin{array}{l}\text { Voltage } \\
\mathrm{V}\end{array}$ & $\begin{array}{l}\text { Current } \\
\mathrm{A}\end{array}$ & $\begin{array}{l}\text { Power } \\
\text { input } \\
\mathrm{kW}\end{array}$ & $\begin{array}{l}\text { Power } \\
\text { factor }\end{array}$ \\
\hline 50.0 & 72.0 & 76.03 & 3.409 & 0.32 \\
\hline
\end{tabular}

\section{No load characteristics}

Graph 1 shows the no load characteristics with voltage on $\mathrm{X}$ axis and power and current on the Yaxis.

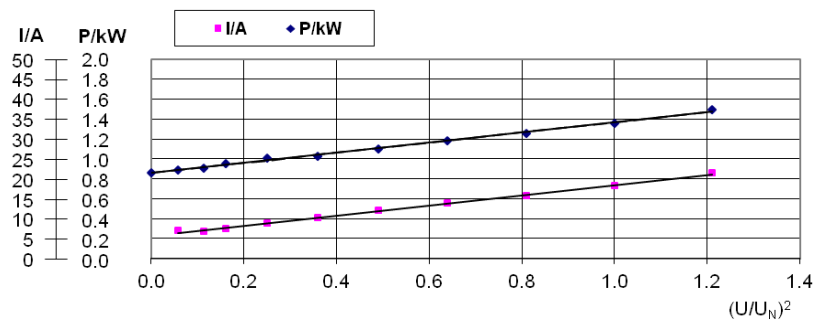

Graph 1

Friction losses: $0.857 \mathrm{~kW}$

Iron losses: $\quad 0.499 \mathrm{~kW}$

D. Table V: Load charcteristics

\begin{tabular}{|c|c|c|c|c|c|c|c|c|c|c|}
\hline \multicolumn{7}{|c|}{ Measured values } & \multicolumn{4}{|c|}{ Calculated values } \\
\hline $\begin{array}{l}\mathrm{f} \\
\mathrm{Hz}\end{array}$ & $\begin{array}{l}\mathrm{U} \\
\mathrm{V}\end{array}$ & $\begin{array}{l}\text { I } \\
\text { A }\end{array}$ & $\begin{array}{l}\mathrm{P}_{1} \\
\mathrm{~kW}\end{array}$ & $\operatorname{Cos} \phi$ & $\begin{array}{l}\mathrm{n} \\
\min ^{-1}\end{array}$ & $\begin{array}{l}\mathrm{T} \\
\mathrm{Nm}\end{array}$ & $\mathrm{P}_{2}$ & $\mathrm{P}_{\mathrm{t}}$ & $\begin{array}{l}\mathrm{P}_{2} / \mathrm{P}_{\mathrm{n}} \\
\%\end{array}$ & $\begin{array}{l}\eta \\
\%\end{array}$ \\
\hline 50 & 415.5 & 131.4 & 84.49 & 0.89 & 2923 & 250 & 76.69 & 7.8 & 170.42 & 90.77 \\
\hline 50 & 415.3 & 93.92 & 61.01 & 0.90 & 2947 & 182 & 56.37 & 4.6 & 125.28 & 92.39 \\
\hline 50 & 415.1 & 75.13 & 48.53 & 0.89 & 2958 & 145 & 45.10 & 3.4 & 100.23 & 92.94 \\
\hline 50 & 415.1 & 57.46 & 36.38 & 0.88 & 2969 & 108 & 33.85 & 2.5 & 75.24 & 93.06 \\
\hline 50 & 415.2 & 41.04 & 24.49 & 0.83 & 2979 & 72.2 & 22.59 & 1.9 & 50.21 & 92.23 \\
\hline 50 & 415.2 & 26.92 & 12.85 & 0.66 & 2988 & 35.9 & 11.31 & 1.5 & 25.15 & 88.02 \\
\hline
\end{tabular}

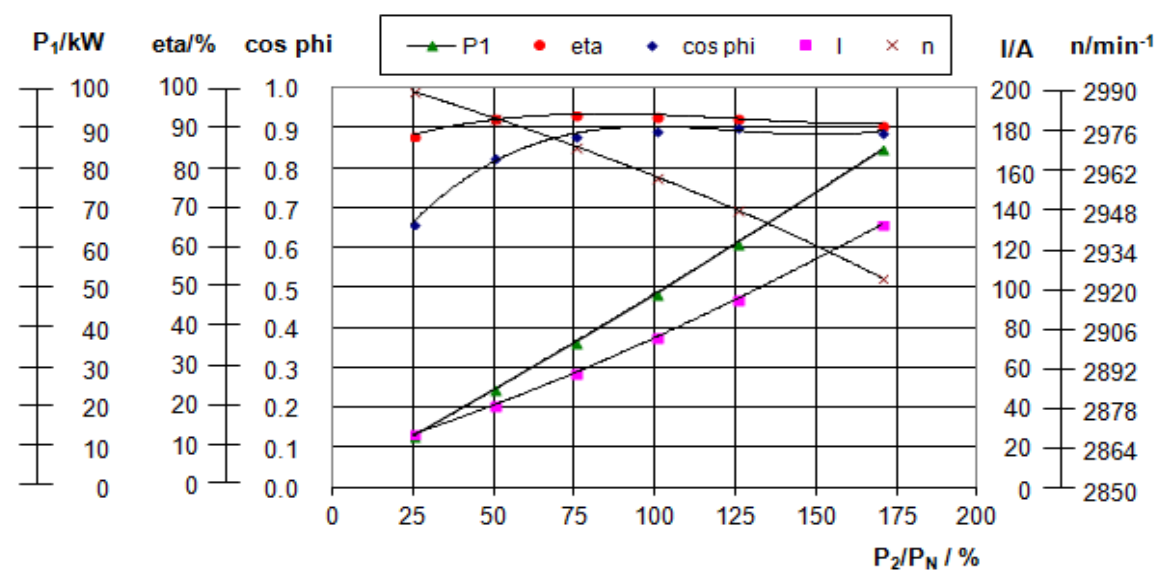

Graph 2 
E. Calculation of individual losses

Table VI: Load data

\begin{tabular}{|c|c|c|c|c|c|c|c|c|c|}
\hline \multicolumn{10}{|c|}{ Measured Values (UN) } \\
\hline $\mathrm{P}_{2} / \mathrm{P}_{\mathrm{N}}$ & $\begin{array}{l}\mathrm{f} \\
\mathrm{Hz}\end{array}$ & $\begin{array}{l}\mathrm{U} \\
\mathrm{V}\end{array}$ & $\begin{array}{l}\mathrm{I} \\
\mathrm{A}\end{array}$ & $\begin{array}{l}\mathrm{P} 1 \\
\mathrm{~kW}\end{array}$ & $\operatorname{Cos} \phi$ & $\begin{array}{l}\mathrm{T} \\
\mathrm{Nm}\end{array}$ & $\begin{array}{l}\mathrm{N} \\
\mathrm{Min}^{-1}\end{array}$ & $S$ & $\begin{array}{l}\mathrm{R} \\
\Omega\end{array}$ \\
\hline 170.42 & 49.96 & 415.5 & 131.40 & 84.492 & 0.89 & 250.3 & 2923.3 & 2.484 & 0.10388 \\
\hline 125.28 & 49.96 & 415.3 & 93.92 & 61.019 & 0.90 & 182.3 & 2947.3 & 1.658 & 0.10388 \\
\hline 100.23 & 49.96 & 415.1 & 75.13 & 48.531 & 0.89 & 145.3 & 2958.7 & 1.303 & 0.10388 \\
\hline 75.24 & 49.96 & 415.1 & 57.46 & 36.384 & 0.88 & 108.6 & 2969.4 & 0.949 & 0.10388 \\
\hline 50.21 & 49.96 & 415.2 & 41.04 & 24.498 & 0.83 & 72.2 & 2979.4 & 0.614 & 0.10388 \\
\hline 25.15 & 49.96 & 415.2 & 26.96 & 12.855 & 0.66 & 35.9 & 2988.5 & 0.311 & 0.10388 \\
\hline
\end{tabular}

Table VII:

\begin{tabular}{|l|l|l|l|l|l|l|l|l|l|}
\hline \multicolumn{2}{|l|}{ Calculation acc. to IEC 60034-2-1 } \\
\hline $\mathrm{P}_{2} / \mathrm{P}_{\mathrm{N}}$ & $\mathrm{P}_{\mathrm{fw}}$ & $\mathrm{P}_{\mathrm{fe}}$ & $\mathrm{P}_{\mathrm{s}}$ & $\mathrm{P}_{\mathrm{r}}$ & $\mathrm{P}_{\mathrm{LL}}$ & $\mathrm{P}_{\mathrm{T}}$ & $\mathrm{P}_{1}$ & $\mathrm{P}_{2}$ & $\begin{array}{l}\eta \\
\%\end{array}$ \\
\hline 170.42 & 0.857 & 0.47 & 2.690 & 2.020 & 1.762 & 7.802 & 84.49 & 76.69 & 90.77 \\
\hline 125.28 & 0.857 & 0.47 & 1.375 & 0.997 & 0.935 & 4.642 & 61.01 & 56.37 & 92.39 \\
\hline 100.23 & 0.857 & 0.48 & 0.879 & 0.615 & 0.594 & 3.427 & 48.53 & 45.10 & 92.94 \\
\hline 75.24 & 0.857 & 0.48 & 0.514 & 0.336 & 0.332 & 2.525 & 36.38 & 33.85 & 93.06 \\
\hline 50.21 & 0.857 & 0.49 & 0.262 & 0.146 & 0.147 & 1.903 & 24.49 & 22.59 & 92.23 \\
\hline 25.15 & 0.857 & 0.49 & 0.113 & 0.038 & 0.036 & 1.540 & 12.85 & 11.31 & 88.02 \\
\hline
\end{tabular}

Table VIII: Calcu lation of additional losses

\begin{tabular}{|c|c|c|c|c|c|c|c|c|c|}
\hline \multicolumn{7}{|c|}{ Measured values } & \multicolumn{3}{|c|}{ Calculated values } \\
\hline $\begin{array}{l}\mathrm{f} \\
\mathrm{Hz}\end{array}$ & $\begin{array}{l}\mathrm{U} \\
\mathrm{V}\end{array}$ & $\begin{array}{l}\mathrm{I} \\
\mathrm{A}\end{array}$ & $\begin{array}{l}\mathrm{P} 1 \\
\mathrm{~kW}\end{array}$ & $\operatorname{Cos} \phi$ & $\begin{array}{l}\mathrm{n} \\
\min ^{-1}\end{array}$ & $\begin{array}{l}\mathrm{T} \\
\mathrm{Nm}\end{array}$ & $\begin{array}{l}P_{\mathrm{L} 1} \\
\mathrm{~kW}\end{array}$ & $\begin{array}{l}\mathrm{P}_{\mathrm{L} 2} \\
\mathrm{~kW}\end{array}$ & $\begin{array}{l}P_{L L} \\
k W\end{array}$ \\
\hline 50.0 & 415.5 & 131.40 & 84.492 & 0.89 & 2923.3 & 250.3 & 1.823 & 1.842 & 1.762 \\
\hline 50.0 & 415.3 & 93.92 & 61.019 & 0.90 & 2947.3 & 182.3 & 1.045 & 1.105 & 0.935 \\
\hline 50.0 & 415.1 & 75.13 & 48.531 & 0.89 & 2958.7 & 145.3 & 0.682 & 0.674 & 0.594 \\
\hline 50.0 & 415.1 & 57.46 & 36.384 & 0.88 & 2969.4 & 108.6 & 0.429 & 0.411 & 0.332 \\
\hline 50.0 & 415.2 & 41.04 & 24.498 & 0.83 & 2979.4 & 72.2 & 0.202 & 0.227 & 0.147 \\
\hline \multirow[t]{3}{*}{50.0} & 415.2 & 26.96 & 12.855 & 0.66 & 2988.5 & 35.9 & 0.104 & 0.116 & 0.036 \\
\hline & & & & & & & A & B & $\gamma$ \\
\hline & & & & & & & $2.81 \mathrm{E}+01$ & 0.080 & 0.999 \\
\hline
\end{tabular}

$\rightarrow P_{\mathrm{L} 1} \rightarrow-\mathrm{P}_{\mathrm{L} 2} \rightarrow \mathrm{P}_{\mathrm{LL}}$

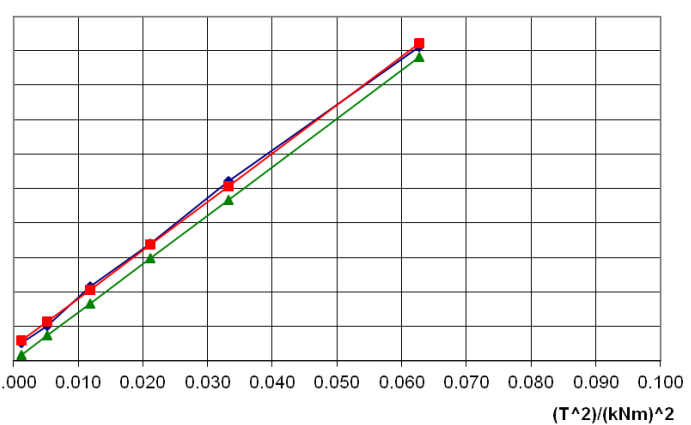

Graph 3

\section{RESULT ANALYSIS AND DISCUSSIONS}

The analytical results of motor are compared with the actual motor parameters in terms of dimensions of stator, stator design, rotor design, performance characteristics, losses and efficiency. This motor was tested at Siemens Advance motor Testing Centre.

Table 1 shows the reference data required for designing of motor. Table 2 shows the calculated parameters of the motor. 
In section $\mathrm{V}$, Type tests performed on the motor and the results of the type test are shown. Graph1 shows the No load characteristics and according to the type test the friction losses and the iron losses are more as compared to calculated losses. Hence these losses are needed to be reduced.

From Table V i.e. Load characteristics, at rated values of voltage, frequency and current, the efficiency obtained is $92.94 \%$. Table VI shows the calculation of individual losses such as friction and windage loss, Iron loss, stator and rotor copper loss, stray load loss etc. The stray load losses can be calculated as per IEC $60034-2-1$ by the following formu la: $\mathrm{P}_{\mathrm{LL}}: \mathrm{P}_{1}\left[0.025-0.05 * \log _{10}\left(\mathrm{P}_{2} / 1 \mathrm{~kW}\right)\right]$

As per IEC 60034-30-1 for premium efficiency motor the minimum efficiency should be $94 \%$. Hence the calculated efficiency is $93.94 \%$ but the type test results shows the efficiency is $92.94 \%$. Hence the motor has failed in efficiency test.

Hence the task is to increase the efficiency as per IS/IEC $60034-1$ which shows that for motor up to and including $150 \mathrm{~kW}$ should have $15 \%$ (of (1- $\eta)$ ) tolerance. Hence as per this tolerance calculation the efficiency of this IE3 motor should be increased up to $94 \%$ with subject to tolerance and $93.1 \%$ inclusive to tolerance.

\section{CONCLUSION}

This paper has presented a Premium efficiency motor (IE3). The actual motor parameters such as stator design, rotor design, and performance is compared with the analytical results. The following conclusions are obtained:

1. As per IEC 60034-30-1 for premium efficiency motor the minimum efficiency should be $94 \%$. Hence the calculated efficiency is $93.94 \%$ but the type test results shows the efficiency is $92.94 \%$.

2. The calculated losses such as friction loss, iron loss are less as compared to motor type test results.

The future work will investigate the various losses in motor and try to reduce those losses in order to increase the efficiency. Following are the approaches to modify the design of motor in order to reduce the losses.

\section{A. Table IX}

\begin{tabular}{|l|l|l|}
\hline Problems & Causes & Solutions \\
\hline Low efficiency & $\begin{array}{l}\text { Large stator } \\
\text { copper loss }\end{array}$ & $\begin{array}{l}\text { 1. Increase wire diameter } \\
\text { 2. Decrease stator turn or coil pitch } \\
\text { 3. Increase power factor }\end{array}$ \\
\cline { 2 - 3 } & $\begin{array}{l}\text { Large core } \\
\text { loss }\end{array}$ & $\begin{array}{l}\text { 1. Decrease flux density by increase stator } \\
\text { turn or coil pitch, and increase length } \\
\text { 2. Use better steel }\end{array}$ \\
\cline { 2 - 3 } & $\begin{array}{l}\text { Large stray } \\
\text { loss }\end{array}$ & $\begin{array}{l}\text { 1. Modify Ns/Nr combination } \\
\text { 2. Increase airgap } \\
\text { 3. Modify rotor skew }\end{array}$ \\
\cline { 2 - 3 } & $\begin{array}{l}\text { Large rotor } \\
\text { copper loss }\end{array}$ & $\begin{array}{l}\text { 1. Increase rotor slot area } \\
\text { 2. Decrease stator turn or coil pitch to } \\
\text { decrease rotor current }\end{array}$ \\
\hline
\end{tabular}

\section{REFERENCES}

[1] Sawhney, A.K., "A Course in Electrical Machine Design”, 6thEdition, Dhanpat Rai and Sons, 2006.

[2] Dr. Bimbhra, P S, Electrical Machinery, Seventh Edition, Khanna Publishers, New Delhi, 2009.

[3] Korea Gyeorye Lee, Seungjae Min, and Jung-Pyo Hong "Optimal Shape Design of Rotor Slot in SquirrelCage Induction Motor Considering Torque Characteristics",IEEE Transactions on magnetics, vol. 49, no.5, may 20132197.

[4] Lloyd, T. C"Some aspects of electric-motor designpolyphase-induction-motor design to meet fixed specification". American Institute of Electrical Engineers,Transactions (Volu me:63,1) January 1944.

[5] "Optimal Design of Rotor Slot Geometry of SquirrelCage Type Induction Motors" Electric Machines \& Drives Conference, 2007. IEMDC '07. IEEE International (Volume:1 ).

[6] J. Faiz, M.B.B. Sharifian,"Optimal design of three phase induction motors and their comparison with a typical industrial motor". Int. J. of Comp. and Elect.Eng. 27:133-144, 2001.

[7] R Fci,E.F.Fuchs,H.Huaugh,"Comparison of two optimization techniques for the design of a three-phase induction motor design", IEEE Trans on Energy Conv.;4(4):651-9, 1989.

[8] Aníbal T. de Almeida, Fernando J. T. E, Ferreira and Ge Baoming"Beyond Induction Motors-Technology Trends to Move Up Efficiency", IEEE transactions on industry applications, vol. 50, no. 3, may/june 2014.

[9] Fernando, J. T. E.Ferreira, An'ibal T. de Almeida, "Novel Multiflux Level Three-Phase, Squirrel-Cage Induction Motor for Efficiency and Power Factor Maximization”, IEEE Transactions on energy conversion, vol. 23, no.1,March 2008.

[10] IEC 60034-30-1

[11] IEC 60034-2-1_2014 (Determination of losses \& efficiency). 